\title{
PERUBAHAN PERAN PEMUKA ADAT PUNYIMBANG PADA MASYARAKAT ADAT PEPADUN
}

\author{
Saras Sarita dan Siti Nurbayani K \\ Mahasiswa Program Studi Pendidiakn Sosiologi FPIPS Universitas Pendidikan Indonesia
}

Email: saras sarita@ymail.com

\begin{abstract}
This study is about the changing role of traditional leaders called punyimbang in pepadun community. This research was conducted in the village of Terbanggi Besar, Terbanggi Besar District of Central Lampung regency. This research was motivated by the social and cultural changes taking place in society. The research is a qualitative research method of case study that compares difference conditions punyimbang role ago and today. The results of this study are firstly the social and cultural changes that occurred in the community so that the role punyimbang the first switch and always involved in every aspect of community life is starting at left, second, the factors that cause changes in this role is the modernization that began touching indigenous peoples pepadun village Terbanggi great so that people began to leave things that are traditional, third, these changes have an impact on the conflict in the community, due to the people lost figure punyimbang that exemplifies the good things that people are starting to do a lot of irregularities such as conflict between villages, spoliation, and the conflict between generations, fourth, related to the changing role of public response punyimbang happens is people still assume the existence punyimbang needed as long as there customary held by the public but does not bind as before.
\end{abstract}

Keywords: Role Changes, punyimbang traditional leaders, indigenous peoples, social and cultural changes

\begin{abstract}
ABSTRAK
Penelitian ini membandingkan perbedaan kondisi peran punyimbang dahulu dan saat ini. Hasil penelitian ini yaitu, pertama adanya perubahan sosial dan budaya yang terjadi pada masyarakat sehingga peran punyimbang yang dahulu sakral dan selalu dilibatkan dalam setiap aspek kehidupan masyarakat saat ini sudah mulai di tinggalkan, kedua, faktor yang menyebabkan terjadinya perubahan peran ini adalah arus modernisasi yang mulai menyentuh masyarakat adat pepadun di Desa Terbanggi Besar sehingga masyarakat mulai meninggalkan hal-hal yang bersifat tradisional,
\end{abstract}


ketiga, perubahan ini berdampak pada konflik yang terjadi pada masayarakat, akibat masyarakat kehilangan sosok punyimbang yang mencontohkan hal-hal baik maka masyarakat mulai banyak melakukan penyimpangan seperti konflik antar kampung, pembegalan, dan konflik antar generasi, keempat, respon masyarakat terkait perubahan peran punyimbang yang terjadi adalah masyarakat masih menganggap keberadaan punyimbang dibutuhkan selama masih ada adat yang dipegang oleh masyarakat tetapi tidak mengikat seperti dahulu.

Kata kunci: Perubahan Peran, Pemuka adat punyimbang, Masyarakat adat, Perubahan sosial budaya

\section{PENDAHULUAN}

Indonesia merupakan Negara kepulauan yang didalamnya terdapat berbagai macam kekayaan dan keanekaragaman, baik alam maupun masyarakatnya. Masyarakat yang tinggal di Indonesia terdiri dari ras etnik dan suku bangsa yang berbeda, karenanya Indonesia disebut Negara multicultural dimana masyarakat yang di dalamnya terdapat beragam kebudayaan. Sejak dahulu di Indonesia telah hidup bermacam-macam masyarakat adat dalam berbagai komunitas. Komunitas-komunitas yang telah ada berkembang dan hidup serta melangsungkan aktifitasaktifitas sosialnya selama ratusan bahkan ribuan tahun di Indonesia dan menghasilkan apa yang disebut sebagai kebudayaan dan kebudayaan antara satu daerah dengan daerah lainnya berbedabeda.

Kebudayaan daerah terlihat dalam berbagai aspek kehidupan masyarakat di seluruh daerah yang ada di Indonesia. Salah satunya adalah organisasi sosial yang berbentuk lembaga pemerintahan dalam masyarakat adat yang ada di Lampung yang lebih dikenal dengan sebutan lembaga perwatin dan kepunyimbangan. Lembaga perwatin dan kepunyimbangan merupakan irisan dan lapisan penting dalam diagram struktur sosial masyarakat Lampung dimana keduanya tidak bisa dipisahkan dari kehidupan sosial masyarakat Lampung. Lembaga ini merupakan mekanisme dan bentuk pemerintahan lokal yang terkait proses kepemimpinan dalam penyelenggaraan sistem kemasyarakatan.

Masyarakat Lampung menggambarkan punyimbang sebagai seseorang yang sudah dan dianggap mampu berdiskusi dalam berbagai hal terkait dengan berbagai aspek dalam kehidupan bermasyarakat suku Lampung, para punyimbang dianggap mampu membantu menyelesaikan masalah yang ada dalam masyarakat. Punyimbang juga diartikan sebagai 
orang yang mampu memberi contoh, yang dimaksud memberi contoh adalah segala perbuatan, tingkah laku dan gerak-gerik punyimbang harus mampu menjadi contoh yang baik bagi orang lain. Dalam setiap kegiatan adat baik itu yang bersifat besar seperti pernikahan atau hanya sekedar urusan masalah kecil antar warga maka punyimbang harus selalu dilibatkan. Para punyimbanglah yang memiliki hak suara untuk memutuskan segala sesuatunya.

Orang Lampung atau yang disebut ulun Lampung memiliki Sikap watak atau pandangan hidup yang disebut Piil Pesenggiri, ini nampak sekali pada lingkungan masyarakat Lampung yang beradat pepadun. Didasari oleh pandangan Piil Pesenggiri yang salah satu unsurnya adalah bejuluk beadek, menghendaki agar seseorang selain mempunyai nama juga diberi gelar panggilan terhadapnya. Sejak dahulu dikatakan bahwa memang orang Lampung suka akan kemegahan dan ingin dihormati sehingga mereka menginginkan naik gelar kegelar yang paling tinggi yaitu punyimbang, jika dalam masyarakat saibatin punyimbang didasarkan ikatan darah atau keturunan, lain halnya dengan masyarakat pepadun, siapapun bisa menjadi punyimbang jika mampu melaksanakan upacara adat begawi cakak pepadun yang merupakan upacara naik gelar ataupun pemberian gelar. Gelar dalam masyarakat Lampung sangat penting seperti gelar suttan, pangeran, rajo, ratu dll. Biasanya saat kumpul keluarga atau dalam acara bersama mereka tidak hanya memanggil nama tapi juga dengan gelarnya dan ini merupakan prestise bagi mereka yang memiliki gelar. Selain menetapkan hukum adat dan menyelesaikan masalah yang terjadi di masyarakatnya, punyimbang memiliki banyak hak khusus tersendiri dalam keluarga maupun dalam kehidupan bermasyarakat.

Perubahan sosial di suatu masyarakat bisa ditandai dengan berubahnya struktur sosial dan budaya sehingga struktur sosial dan budaya suatu masyarakat berubah menjauhi bentuknya terdahulu. Perubahan sosial seperti ini akan terjadi jika perubahan pada berbagai organisasi sosial dan persepsi masyarakat pada nilai-nilai kehidupan seperti yang terlihat dalam perkembangan masyarakat adat pepadun Terbanggi Besar. Dengan demikian bisa terjadi perubahan dalam hal-hal yang semula dipercaya dan dianggap sakral atau penting menjadi hal yang tidak ada artinya. Modernisasi dan perkembangan ilmu yang semakin besar menggerakan perubahan struktur masyarakat dari sistem tradisional menuju masyarakat modern yang lebih berorientasi pada nilai-nilai materi.

Dalam beberapa buku seperti yang ditulis oleh Hadikusuma yang mengkaji masyarakat dan adat budaya Lampung bahwa lembaga kepunyimbangan dianggap sebagai tradisi yang sudah lapuk, melestarikan feodalistik yang 
bertentangan dengan modernism dan hal yang mubazir yang menghambur-hamburkan biaya dalam pelaksanaan upacara cakak pepadun (upacara cakak pepadun adalah upacara naik gelar). Pernyataan ini sesuai dengan apa yang saat ini terjadi, masyarakat yang mulai terbuka dan maju dalam berfikir menganggap punyimbang hanya pelengkap suatu acara yang tidak terlalu didengar pendapatnya, pendapat punyimbang, keputusan punyimbang dan rasa hormat pada para punyimbang akan kalah dengan pendapat mereka yang memiliki gelar pendidikan tinggi atau mereka yang memiliki pekerjaan dan harta yang mapan, terlebih lagi dengan banyaknya muncul spesialisasi pekerjaan baru, hal ini mumunculkan stratifikasi sosial yang tidak lagi didasari oleh gelar bangsawan saja.

Perubahan yang terjadi pada masyarakat dan menggeser peran para punyimbang juga berpengaruh terhadap penyelesaian konflik yang terjadi dalam kehidupan sosial masyarakat pepadun Terbanggi Besar.

Melihat fenomena perubahan kedudukan dan peran punyimbangan yang terjadi maka itu peneliti merasa perlu adanya penelitian lebih dalam pada masyarakat adat pepadun Terbanggi Besar. Tujuan yang hendak dicapai dalam penelitian perubahan peran punyimbang pada masyarakat adat pepadun Terbanggi Besar ini adalah mendapatkan gambaran mengenai sejauh apa perubahan yang terjadi pada peran pemuka adat punyimbang di tengah kondisi masyarakat Lampung yang semakin tergeser oleh pendatang dan arus modernisasi.

\section{METODE PENELITIAN}

Menurut Sugiyono (2009, hlm.2) "metode penelitian pada dasarnya merupakan cara ilmiah untuk mendapatkan data dengan tujuan dan kegunaan tertentu". Berdasarkan hal tersebut terdapat empat kata kunci yang perlu diperhatikan yaitu cara ilmiah, data, tujuan, dan kegunaan. Cara ilmiah berarti kegiatan penelitian itu didasarkan pada ciri-ciri keilmuan yaitu rasional, empiris, dan sistematis. Rasional berarti kegiatan penelitian dilakukan dengan cara yang masuk akal. Empiris berarti cara-cara dalam penelitian dilakukan dengan indra manusia. Sistematis berarti proses yang dilakukan dalam penelitian dilakukan melalui langkah-langkah tertentu yang bersifat logis.

Pendekatan kualitatif dirasa pantas digunakan dalam penelitian ini berkaitan dengan tujuan dan kajian yang hendak dicapai penulis. Inti dari penelitian ini adalah mengkaji pola komunikasi dan hubungan antara aspek aspek budaya dan sosial yang saling mempengaruhi dalam kehidupan masyarakat, sehingga data yang hendak didapat peneliti tidak bias didapat dengan menggunakan pendekatan statistik. Seperti yang diungkapkan oleh Rudito \& Famiola 
(2013, hlm. 78-79) "bukan variablevariable yang dianalisis dalam kaitan hubungan dengan prinsip-prinsip umum dari satuan-satuan gejala lainnya dengan menggunakan budaya masyarakat yang diteliti dan dari hasil analisis tersebut dianalisis lagi dengan menggunakan seperangkat teori yang berlaku. Metode kualitatif dilakukan pada kondisi alamiah sebagai realitas sosial yang dipandang sesuatu yang holistic atau utuh, kompleks, dinamis dan penuh makna. Hal ini sejalan dengan yang diungkapkan oleh Moleong (2004, hlm.26) bahwa:

Penelitian kualitatif adalah penelitian yang bermaksud memahami fenomena tentang apa yang dialami oleh subjek penelitian secara holistic dan dengan cara deskriptif dalam bentuk kata-kata dan bahasa, pada suatu konteks kusus yang alamiah dan dengan memanfaatkan berbagai metode alamiah.

Lebih lanjut lagi Creswell (2010, hlm.4) mengungkapkan bahwa:

Proses penelitian kualitatif ini melibatkan upaya-upaya seperti mengajukan pertanyaan-pertanyaan dan prosedur-prosedur,

mengumpulkan data yang spesifik dari para partisipan, menganalisis data secara induktif mulai dari tema-tema yang khusus ketema-tema yang umum dan menafsirkan makna data. Lapora akhir untuk penelitian ini memiliki krangka yang fleksibel. Siapapun yang terlibat dalam bentuk penelitian ini harus menetapkan cara pandang penelitian yang bergaya induktif, berfokus terhadap makna individual dan menerjemahkan kompleksitas suatu persoalan.

Dapat disimpulkan bahwa penelitian kualitatif merupakan pendekatan penelitian ilmiah yang menitik beratkan pengkajian objek secara alamiah dan hasil akhirnya berupa data deskriptif dari sumber yang diamati.

Untuk melengkapi penelitian yang berkaitan dengan perubahan peran pemuka adat punyimbang pada masyarakat adat pepadun peneliti merasa perlu menggunakan metode studi kasus, seperti yang diungkapkan oleh Stake (dalam Creswell, 2010, hlm. 20) bahwa "studi kasus merupakan strategi penelitian di mana di dalamnya peneliti menyelidiki secara cermat suatu program, peristiwa, aktivitas, proses, atau sekelompok individu. Kasus-kasus dibatasi oleh waktu dan aktivitas, dan peneliti menggumpulkan informasi secara lengkap dengan menggunakan berbagai prosedur pengumpulan data berdasarkan waktu yang telah ditentukan". Strategi penelitian ini dirasa sesuai dengan apa yang ingin peneliti capai, dan sesuai dengan konsep perubahan sosial seperti yang diungkapkan oleh Sztompka (dalam Martono, 2011, hlm.2), yaitu:

1. Studi mengenai perbedaan;

2. Studi perlu dilakukan pada waktu yang berbeda;

3. Pengamatan pada sistem sosial yang sama; 
HASIL DAN PEMBAHASAN

Gambaran perubahan peran punyimbang pada masyarakat adat pepadun di Desa Terbanggi Besar

Masyarakat Lampung pepadun memiliki kepala pemimpin yang disebut punyimbang, punyimbang berperan sebagai pemuka adat, tidak hanya itu punyimbang sendiri banyak memiliki arti yaitu tempat menimbang-nimbang dan juga tempat memberi contoh baik. Di katakan tempat menimbangnimbang karena tugas punyimbang adalah untuk berdiskusi dalam sidang adat yang membahas masalah yang terkait dengan kehidupan masyarakat, jika dahulu ketika masyarakat adat yang memiliki masalah maka yang dicari adalah punyimbang, mereka akan meminta bantuan punyimbang untuk membantu menyelesaikan masalahnya maka dahulu jarang ada masalah yang berlarut-larut sampai ke meja hijau, biasanya masalah dapat diselesaikan dengan musyawarah antara para punyimbang. Di katakan juga punyimbang merupakan tempat memberi contoh yang baik kepada masyarakat hal ini tercermin dengan adanya cepalo atau aturan adat yang mengikat kehidupan punyimbang.

Peran punyimbang dalam masyarakat terlihat dalam semua aspek kehidupan mulai dari seseorang lahir hingga menikah hingga meninggal, punyimbang juga mengurusi masalah yang terjadi di dalam kehidupan masyarakat. Saat ini peran punyimbang mulai mengalami perubahan, masyarakat mulai berkembang baik dalam pemikiran maupun dalam praktek kehidupan sehari-hari. gelar adat seperti punyimbang mulai ditinggalkan dan dianggap tidak terlalu penting serta hanya melestarikan feodalisme. Seiring berkembangnya zaman dan pemikiran masyarakat saat ini stratifikasi dalam masyarakat mulai berdasarkan pada keahlian ataupun gelar-gelar pendidikan seseorang, seseorang akan di hormati ketika ia memiliki gelar pendidikan tinggi atau memiliki kondisi ekonomi yang baik. Masyarakat mulai bersifat matrealistis dalam memandang segala sesuatu, upacara pengambilan gelar adat seperti punyimbang saat ini dianggap sebuah pemborosan.

Saat ini peran punyimbang hanya terlihat sebatas pada upacara pernikahan adat, dan aturan adat seperti cepalo pun mulai hilang, terlihat dari tahun 1986 di mana cepalo berjumlah 240 kini hanya terisisa 12 cepalo saja yang masih ada, hal ini dikarenakan banyak aturan dalam cepalo yang dianggap tidak sesuai lagi dengan perkembangan zaman dan sulit diterapkan.

Faktor-faktor penyebab perubahan peran punyimbang pada masyarakat adat pepadun di Desa Terbanggi Besar 
Perubahan peran pemuka adat punyimbang pada masayarakat pepadun di Desa Terbanggi Besar disebabkan oleh banyak hal seperti modernisasi, kemajuan teknologi, banyaknya pendatang yang masuk ke daerah Lampung, pendidikan yang semakin maju sehingga pikiran masyarakat pun ikut berubah dan mulai meninggalkan hal-hal yang berbau tradisional.

Banyaknya pendatang yang masuk ke daerah Lampung semakin menggeser tempat penduduk asli Lampung, hal ini terlihat dari komposisi penduduk di Kecamatan Terbanggi Besar yang hanya 10\% nya adalah masyarakat Lampung asli sisanya adalah pendatang dari Jawa, Bali dan daerah lain. Penduduk asli paling banyak terdapat di Desa Terbanggi Besar. Dengan banyaknya pendatang maka budaya dan tradisi daerah asli juga semakin sulit untuk di perkenalkan. Masyarakat yang heterogen juga berpengaruh terhadap perubahan peran punyimbang yang terjadi. Selain itu modernisasi dan pendidikan yang semakin berkembang juga merubah pemikiran masyarakat yang semula tradisional menjadi modern dan tidak terikat lagi oleh hukum ataupun aturan adat.

Dampak yang ditimbulkan akibat adanya perubahan peran pemuka adat punyimbang terhadap konflik yang terjadi dalam masyarakat adat pepadun di Desa Terbanggi Besar
Dampak akibat perubahan ini terlihat pada konflik dan cara penanganan konflik yang terjadi di dalam kehidupan masyarakat Desa Terbanggi Besar, jika dahulu penyelesaian konflik melibatkan punyimbang sebagai pihak yang mampu menengahi dan menyelesaikan konflik yang ada, saat ini tidak lagi seperti itu. Masyarakat mulai mengganti peran punyimbang dengan pihak lain yang dianggap lebih mampu menyelesaikan konflik seperti polisi, ataupun ustad. Peran punyimbang sebagai tempat pemberi contoh yang baik dengan menerapkan dan melaksanakan aturan adat yang disebut cepalo pun saat ini mulai ditinggalkan, sehingga punyimbang hanyalah sebatas gelar adat saja. Jika dalam masyarakat sudah mulai kehilangan role model tentang contoh perbuatan baik dan ketika kontrol sosial dari punyimbang mulai melemah maka konflik sosial dalam masyarakat sangat mungkin terjadi. Bentuk konflik yang biasa terjadi adalah konflik antar kampung, konflik antara generasi muda dan generasi tua, adanya pemalakan liar sampai aksi begal yang dilakukan oleh oknum yang tidak bertanggung jawab.

Respon masyarakat terhadap perubahan peran pemuka adat punyimbang di Desa Terbanggi Besar.

Respon masyarakat pepadun di Desa Terbanggi Besar dalam menyikapi perubahan peran pemuka adat punyimbang yang terjadi 
sangat beragam, ada beberapa masyarakat yang menyadari adanya perubahan peran punyimbang dan menganggapnya sebagai hal wajar ada pula yang tidak menyadari telah terjadi perubahan dalam peran maupun kedudukan punyimbang.

Menurut

masyarakat perubahan ini dianggap sesuatu yang wajar karena memang ada beberapa aspek terkait peran dan kedudukan punyimbang yang seiring berkembangnya zaman sudah mulai sulit untuk diaplikasikan. Menurut masyarakat wajar saja jika dahulu peran dan kedudukan punyimbang sangat dihormati dan menyangkut banyak aspek dalam kehidupan masyarakat karena saat itu transportasi, dan akses keluar sangat susah, dimana kantor polisi jaraknya sangat jauh dari desa. Saat ini akses informasi sudah sangat terbuka dan maju sehingga pertukaran informasi yang berujung pada modernisasi serta kemajuan masyarakat dalam berfikir, hal ini menyebabkan perubahan peran punyimbang dianggap hal yang wajar oleh masyarakat pada masa kini. Meski demikian masyarakat masih menganggap bahwa keberadaan punyimbang saat ini masih diperlukan karena selama masih ada adat dan tradisi maka disitu masih dibutuhkan punyimbang. Menurut masyarakat hanya punyimbanglah yang memahami hukum adat ataupun tata cara adat dalam upacara pernikahan ataupun hal lain yang menyangkut adat.

\section{SIMPULAN}

Perubahan sosial budaya yang terjadi pada masyarakat adat pepadun merupakan hal yang wajar terjadi, masyarakat senantiasa berubah dan hal ini merupakan salah satu cara agar masyarakat tersebut tetap eksis mengikuti zaman yang berkembang. Perubahan yang terjadi pada peran punyimbang dalam masyarakat pepadun terjadi karena pemikiran masyarakat yang semakin maju dan berkembang sehingga mempengaruhi cara pandang masyarakat terhadap punyimbang, punyimbang yang dahulu dianggap penting saat ini perannya dan aturan adatnya tidak lagi mengikat masyarakat, adat kini lebih fleksibel mengikuti zaman.

\section{DAFTAR RUJUKAN}

Creswell, J.W. (2010). Research Design: Pendekatan Kualitatif, Kuantitatif, dan Mixed. Yogyakarta: Pustaka Pelajar.

Hadikusuma, Hilman (1990). Masyarakat dan Adat Budaya Lampung. Bandung: Mandar Maju.

Martono, Nanang. (2011). Metode Penelitian Kuantitatif. Jakarta : PT Raja Grafindo Persada

Moleong, J.X. (2000). Metode Penelitian Kualitatif. Bandung : PT Remaja Rosdakarya.

Rudito, Bambang dan Famiola, Melia. (2013). Metode Pemetaan Sosial. Bandung: Rekayasa Sains. 
Sosietas Vol. 6 No.2, September 2016

Sugiyono.(2009). Memahami

Penelitian Kualitatif. Bandung

: Alfabeta 